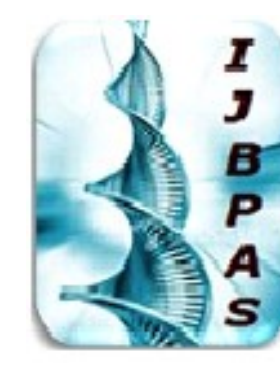

International Journal of Biology, Pharmacy and Allied Sciences (IJBPAS)

'A Bridge Betueen Caboratory and Q ando'

WwW.ibpas.com

REGULATORY OVERVIEW OF NEW DRUGS AND CLINICAL TRIALS RULE

2019: EXPEDITIOUS APPROACHABILITY OF CLINICAL TRIAL AND

BIOAVAILABILITY/BIOEQUIVALENCE STUDY AND ITS INCREASING

VALUES OF INDIAN REGULATIONS ON GLOBAL MARKET

MOULI CHANDAR M ${ }^{1 *}$ AND RANI $S^{2}$

1: Master of Pharmacy, Industrial Pharmacy, Department of Pharmacy, Annamalai

University, Annamalai Nagar, Chidambarm-608002

2: Associate Professor, Department of Pharmacy, Annamalai University, Annamalai Nagar,

Chidambarm-608002

*Corresponding Author: Mouli Chandar M: E Mail: mouli231197@gmail.com; 9600213197

Received $3^{\text {rd }}$ Sept. 2020; Revised $6^{\text {th }}$ Oct. 2020; Accepted $15^{\text {th }}$ Nov. 2020; Available online $1^{\text {st }}$ Aug. 2021

https://doi.org/10.31032/IJBPAS/2021/10.8.5598

\begin{abstract}
To accomplish the objective of expeditious approachability of new drugs for approval and to promote clinical research in par with developed countries clinical trials regulation, "New drug and clinical trials rules,2019" was notified by Union ministry of health and family welfare in official gazette on 19th march 2019 under GSR 227(E) after consultation with drug technical advisory board(DTAB).This rule replaced Part XA and Schedule Y of Drugs and Cosmetic Rules, 1945 but license ,orders ,directions will continue to remain valid. This rule would apply to all new drugs, investigational drugs, bioequivalence and bioavailability study and ethics committee. This review highlights NDCT rules 2019 of India, expedited approval of clinical trials and BA/BE studies, which facilitated private business interests in the conduct of these trial in India. As a result, these will make India to be suitable center for conducting the trials, simultaneously increasing values of Indian regulation on global market.
\end{abstract}

Keywords: Clinical Trial, Bioequivalence, Indian regulations

\title{
INTRODUCTION
}

Clinical Research is medical research, on. It is divided into two further types, which involves human to conduct research observational studies and clinical trials. 
Observational studies, which will observe people involved in studies. Comparative data collected over period of time from people in every distinct characteristic, it may help to see possibilities for clinical trials. These data are collected by researchers by Medical Exams, tests etc., Clinical studies focused to evaluate Quality, safety and efficacy of new drug. It is performed by following clinical trial protocol, which should be approved by Ethical committee after securitization to ensure people's safety. It is performed for Major (CVS, Cancer treatments) as well as minor disease [1]. Clinical trials further classified into phases each of them has specific parameters to evaluate and are specified in Table 1.

Table 1: Types of Clinical Trials [1]

\begin{tabular}{|c|c|c|c|c|}
\hline $\begin{array}{c}\text { Phases of Clinical } \\
\text { trials }\end{array}$ & Study & $\begin{array}{c}\text { Number of } \\
\text { subjects }\end{array}$ & Period & $\begin{array}{c}\text { Specific evaluation of } \\
\text { phases }\end{array}$ \\
\hline Phase I & $\begin{array}{c}\text { Human } \\
\text { Pharmacology study }\end{array}$ & $\mathbf{2 0 - 2 0 0}$ & Several months & Safety, pharmacokinetics \\
\hline Phase II & $\begin{array}{c}\text { Therapeutic } \\
\text { Exploratory study }\end{array}$ & $\begin{array}{c}\text { Several } \\
\text { hundreds }\end{array}$ & $1-3$ years & $\begin{array}{c}\text { Safety, pharmacokinetics, } \\
\text { Efficacy }\end{array}$ \\
\hline Phase III & $\begin{array}{c}\text { Therapeutic } \\
\text { Confirmatory study }\end{array}$ & $\begin{array}{c}\text { Several } \\
\text { hundreds to } \\
\text { thousands }\end{array}$ & $1-4$ years & Safety, Efficacy \\
\hline Phase IV & Post marketing study & On market level & $\begin{array}{c}\text { Subsequent year } \\
\text { after approval }\end{array}$ & $\begin{array}{c}\text { Safety, efficacy on larger } \\
\text { group }\end{array}$ \\
\hline
\end{tabular}

\section{REGULATIONS IN INDIA FOR}

\section{CLINICAL TRIALS}

For conducting clinical trials in India, there are specific guidelines to follows and several committees to get approval. They are

- New Drug and Clinical Trials Rules, 2019 (Second Schedule) under D \& C Act, 1940 and Rules there under 1945.

- Institute Animal Ethics Committee (IAEC).

- Committee for Purpose of Control \& Supervision of Experiments in Animals (CPCSEA).

- Department of Biotechnology, Ministry of Science \& Technology
Review Committee for Gene Manipulation (RCGM).

- Second Schedule of NDCT Rules, 2019.

- Requirements and guidelines for permission to import or manufacture of new drugs for sale or to undertake clinical trial in India [2].

\section{TYPES OF STUDIES REQUIRED FOR PRE-CLINICAL TRIAL}

The objective of preclinical trial is to develop adequate data by testing the new drug on animal subjects and to reasonably decide that it is safe to proceed for human trials. The following studies are mandatory in a preclinical trial [3]. 


\section{Animal toxicology study:}

- Systemic toxicity studies

- Repeated-dose systemic toxicity studies

- Dose-ranging study

- Male fertility study

- Female reproduction and developmental toxicity study

- Female fertility study

- Teratogenicity study

- Perinatal study

- Local toxicity

- Dermal toxicity study

- Photo-allergy or dermal photo toxicity

- Vaginal toxicity test

- Rectal tolerance test

- Parenteral drugs

- Ocular toxicity studies

- Inhalation toxicity study

- Allergenicity or hypersensitivity

- Guinea pig maximization test

- Local lymph node assay

- Genotoxicity

- Carcinogenicity

\section{Animal pharmacology:}

- Specific pharmacological actions

- General pharmacological actions

- Cardiovascular system

- Respiratory system

- Follow-up and supplemental safety pharmacology studies

- Follow-up safety pharmacology studies
- CVS, CNS, respiratory system studies

- Supplemental safety pharmacology studies

- Urinary, Autonomic Nervous System (ANS),gastrointestinal and other organ system

\section{REGULATORY OVERVIEW OF NEW DRUGS AND CLINICAL TRIALS RULE 2019}

On 25 March 2019 [Ref Ministry of Health GSR Notification \# 227 dated 19 March 2019], the "New Drugs and Clinical Trials Rules, 2019" was notified by the Ministry of Health and Family Welfare [MoHFW]. The new rules are aimed at encouraging clinical research in the country and will change the regulatory framework for new drug approval and clinical trial conduct in the country.

By 21 Sep 2019, Chapter IV, which contains guidelines for the 'Ethics Committee for Biomedical and Health Research" was introduced.

This applies to all experimental medicines, new human-use investigational drugs, clinical trials, bioequivalence tests, bioavailability studies, and the Ethics Committee. It provides a great deal of knowledge with immediate effect other than Part XA and Schedule Y of the Drugs and Cosmetics Laws. In the event of any discrepancy between those rules and any other regulation under the Drugs \& 
Cosmetics Act, the provisions of these rules shall take precedence over those other provisions. Actions which have been taken according to Drugs \& Cosmetics Rules,
1945 shall continue to be in effect and valid, which denotes existing licenses, orders, directions will continue to remain valid [4].

Table 2: Types of Application and its Fees

\begin{tabular}{|c|c|}
\hline Type of Applications & Fee Structure (INR) \\
\hline CT Phase I & $\mathbf{3 l a k h s}$ \\
\hline CT Phase II & $1-2$ lakh \\
\hline CT Phase III & 5 lakhs \\
\hline CT Phase IV & $\mathbf{5 0 , 0 0 0}$ \\
\hline Reconsideration of CT Application & $\mathbf{5 0 , 0 0 0}$ \\
\hline Pre submission meeting & $\mathbf{5 0 , 0 0 0}$ \\
\hline Post submission meeting & $\mathbf{5 l a k h}$ \\
\hline BA/BE Study & $\mathbf{5 l a k h}$ \\
\hline New drug Permission/ Finished formulation or API & $\mathbf{2 l a k h}$ \\
\hline Reconsideration of BA/BE Study Application & $\mathbf{5 0 , 0 0 0}$ \\
\hline BA/BE Study center & $\mathbf{5 l a k h}$ \\
\hline Reconsideration of BA/BE Study center Application & $\mathbf{5 0 , 0 0 0}$ \\
\hline
\end{tabular}

Table 3: Forms for Clinical Trial

\begin{tabular}{|c|c|}
\hline Form CT04 & Clinical Trial Application Form (Replaces Form 44) \\
\hline Form CT 04 A & Automatic Approval Information to CDSCO \\
\hline Form CT 06 & Permission to Conduct CTs by CDSCO (Replaces from \\
& 122 DA) \\
\hline Form CT 16 & $\begin{array}{c}\text { Application to grant of License to Import of New Drug } \\
\text { for Clinical Trials (Replaces Form 12) }\end{array}$ \\
\hline
\end{tabular}

Table 4: Detailed Structure of New Drug and clinical Trial Rule 2019 [4]

\begin{tabular}{|c|c|c|c|}
\hline CHAPTER & Title & $\begin{array}{c}\text { Rules } \\
\text { applicable }\end{array}$ & Content \\
\hline 1 & $\begin{array}{c}\text { Short title commencement and } \\
\text { applicability }\end{array}$ & 1,2 & $\begin{array}{l}\text { Definitions: Academic clinical trial, Act, } \\
\text { API, AE, SAE, CLA, SLA, Orphan Drug, } \\
\text { Phytopharmaceutical drug, similar } \\
\text { biologics, sponsor, trial subject }\end{array}$ \\
\hline 2 & Authorities and Officers & $3,4,5$ & $\begin{array}{l}\text { Central Licensing Authority, Delegation of } \\
\text { powers of Central Licensing Authority, } \\
\text { Controlling officer }\end{array}$ \\
\hline 3 & $\begin{array}{l}\text { Ethics Committee for clinical trial, } \\
\text { Bioavailability and bioequivalence study }\end{array}$ & 6 to 14 & $\begin{array}{l}\text { Requirement, Constitution, Registration, } \\
\text { renewal, functions, Proceedings of the ethics } \\
\text { committee }\end{array}$ \\
\hline 4 & $\begin{array}{l}\text { Ethics committee for Biomedical and } \\
\text { Health Research }\end{array}$ & 15 to 18 & $\begin{array}{c}\text { Constitution, Registration of ethics } \\
\text { committee for biomedical and health } \\
\text { research }\end{array}$ \\
\hline 5 & $\begin{array}{c}\text { Clinical Trial Bioavailability and } \\
\text { Bioequivalence study of new drugs and } \\
\text { Investigational New drugs }\end{array}$ & 19 to 30 & $\begin{array}{l}\text { Permission to conduct CT of IND, } \\
\text { conditions of Permission, Validity period of } \\
\text { permission to initiate CT. Academic CT. }\end{array}$ \\
\hline 6 & Compensation & 31 to 38 & $\begin{array}{l}\text { Part A clinical trial, Part B Bioavailability } \\
\text { and Bioequivalence (BA\&BE) Study }\end{array}$ \\
\hline 7 & $\begin{array}{c}\text { Bioavailability and Bioequivalence study } \\
\text { center }\end{array}$ & 39 to 43 & $\begin{array}{c}\text { Registration, Application, Inspection of } \\
\text { Bioavailability (BA) and Bioequivalence } \\
\text { (BE) study center }\end{array}$ \\
\hline 8 & $\begin{array}{l}\text { Manufacture of new drug /Investigational } \\
\text { New drug for clinical trial, bioavailability } \\
\text { or Bioequivalence Study or For } \\
\text { Examination, test and analysis }\end{array}$ & 52 to 66 & $\begin{array}{c}\text { Application for permission, license, } \\
\text { Validity, conditions }\end{array}$ \\
\hline 9 & $\begin{array}{l}\text { Import of New Drug ad Investigational } \\
\text { New Drug for Clinical trial or } \\
\text { bioavailability or bioequivalence study or } \\
\text { for Examination, test and analysis }\end{array}$ & 67 to 73 & Application License, Validity, Condition \\
\hline 10 & $\begin{array}{l}\text { Import or manufacture of New drug for } \\
\text { sale or for distribution }\end{array}$ & 74 to 85 & $\begin{array}{c}\text { Application for permission, license, validity, } \\
\text { condition }\end{array}$ \\
\hline
\end{tabular}




\begin{tabular}{|c|c|c|c|}
\hline 11 & $\begin{array}{c}\text { Import or manufacture of unapproved } \\
\text { New drug for treatment of patents in } \\
\text { government hospital and gov medical } \\
\text { institution }\end{array}$ & $\mathbf{8 6}$ to 96 & $\begin{array}{c}\text { Application for permission, license, validity, } \\
\text { conditions. }\end{array}$ \\
\hline 12 & $\begin{array}{c}\text { Amendments of drugs and cosmetics rules } \\
1945 \text { (Non-Applicability of Schedule Y\& } \\
\text { Part X A) }\end{array}$ & 97 & $\begin{array}{c}\text { Non-application of certain rules for new } \\
\text { drugs and Investigational new drugs for } \\
\text { human use }\end{array}$ \\
\hline 13 & $\begin{array}{c}\text { Miscellaneous } \\
\text { (3) }\end{array}$ & $\mathbf{9 8}$ to 107 & $\begin{array}{c}\text { Pre submission and post submission } \\
\text { meeting, constitution of expert committee, } \\
\text { mode of payment of fee, debarment of } \\
\text { applicant }\end{array}$ \\
\hline
\end{tabular}

\section{APPROVAL PROCESS TO CONDUCT CLINICAL TRIALS}

The redefined timeline for conducting clinical trials in India are

- For Innovated product in India, It shall be disposed within 30 days

- For Drug product which already approved in other than India, then timeline shall be within 90 days

- Reviewing period of Import license is 7 days

If CLA fails to communicate, "Permission to conduct the clinical trial shall be deemed to have been granted".

- Validity period of permission to initiate a clinical trial period of two years from the date of its issue.

- CT initiated only after getting approval from CLA

- If Site of clinical trial does not have Ethical committee, shall get Approval of protocol from EC and that should forward to CLA within 15 days.

- CT site registered with CTRI and should follow Good Clinical Practices.
- Six months status should be reported to CLA. In case of injury, in due time shall be forwarded to CLA and Ethical committee and have to provide compensation according to its severity.

- CT site shall be open for Inspection by CLA and SLA and to seize product for test.

- Non compliance of stipulated conditions may lead to suspension or cancellation of permission to conduct clinical trial [2].

The Schematic representation for approval Process of clinical Trial is given in Flowchart 1.

\section{BIOEQUIVALENCE}

The absence of a substantial difference in the rate and degree to which the active ingredient or active moiety in pharmaceutical equivalents or pharmaceutical substitutes, when administered at the same molar dose under similar conditions in a properly designed sample, is available at the drug site of action. 
The practical importance of $\mathrm{BA} / \mathrm{BE}$ testing has been demonstrated by a number of clinical reports in the 60's and the 70's documenting medical problems due to bioin equivalence. The output of the pharmaceutical dosage form containing the active drug should be known and reproducible in order to allow for therapeutic effect prediction.

It is therefore important to provide fair assurance that different goods containing the same active ingredients, put on the market by different licensees, are clinically equivalent and interchangeable [5].

- For the comparison of two pharmaceutical products containing the same active ingredient, bioequivalence studies should be performed. The studies should provide an objective means to objectively examine the probability of using them in an alternative way. To be considered interchangeable, two products sold by separate licensees containing the same active ingredient(s) must be shown to be therapeutically similar to each other.

- Bioavailability and bioequivalence study center mean a center created or established to undertake bioavailability study or bioequivalence study of a drug for either clinical part or for both clinical and analytical part of such study [6].

\section{TESTS TO ACCESS BIOEQUIVALENCE}

- Comparative studies of bioavailability (bioequivalence) in which an active drug or one or more metabolites are assessed in an accessible biological fluid such as plasma, blood or urine

- Comparative pharmacodynamics studies in humans

- Comparative clinical trials

- In-vitro dissolution test

For certain drugs and dosage forms, in vivo documentation of bioequivalence is important. These include

A. Oral immediate drug release formulations with systemic action when one or more of the following criteria apply:

- Indicated for serious conditions requiring assured therapeutic response.

- Narrow therapeutic window/ safety margin; steep dose response curve.

- Complicated pharmacokinetics.

- Unfavorable physiochemical properties.

- Bioavailability problems related to the drug or drugs of similar chemical structure or formulations 
where a high ratio of excipients to active ingredients exists.

B. Non-oral and non-parenteral drug formulations designed to act by systemic absorption.

C. Sustained or otherwise modified release drug formulations designed to act by systemic absorption.

D. Fixed-dose combination products with systemic action.

E. Pharmaceutical non-solution products intended for non-systemic application (oral, nasal, ocular, dermal, rectal, vaginal, etc.) and for performing without systemic absorption. In these cases, the principle of bioequivalence is not sufficient, and to prove equivalence, comparative clinical or pharmacodynamic studies are needed. To evaluate unintended partial absorption, there is a need for drug concentration measurements [7].

Bioequivalence is not required when the new drug is to be administered parenterally, a solution for oral use, gas, powder for reconstitution as a solution, an otic or ophthalmic or topical product prepared as aqueous solution and an inhalation product or a nasal spray.
APPROVAL PROCESS TO BA/BE STUDY:

Schematic representation of approval process of $\mathrm{BA} / \mathrm{BE}$ study is given in Flowchart 2.

- Every person associated with the conduct of $\mathrm{BA} / \mathrm{BE}$ study of a new drug or IND shall follow the general principle and practices as specified in the First Schedule.

- No BA/BE study of new drug or IND shall be conducted without permission of CLA and approval by EC.

- The work of every BA/BE study center shall be overseen by EC before initiation and throughout the duration of the conduct of the study.

- By making an application in Form CT-05.

- Fees as per Sixth Schedule and other information and documents as specified in table 2 of Fourth Schedule.

- No fee for conducting BA/BE by central and state government funded institution.

- The permission to conduct $\mathrm{BA} / \mathrm{BE}$ study will be valid for one year. 


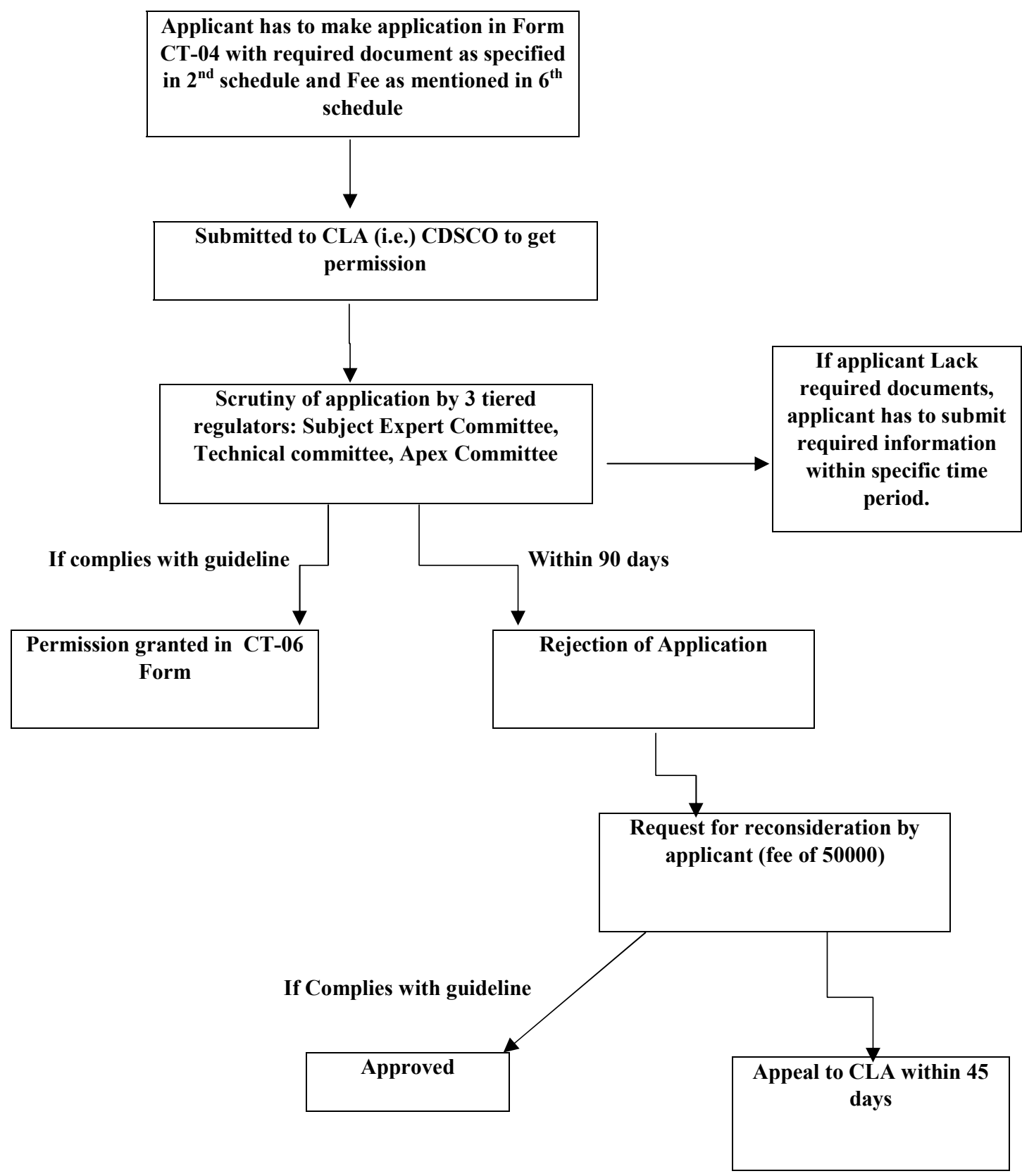

Flowchart 1: Approval Process of clinical Trial 


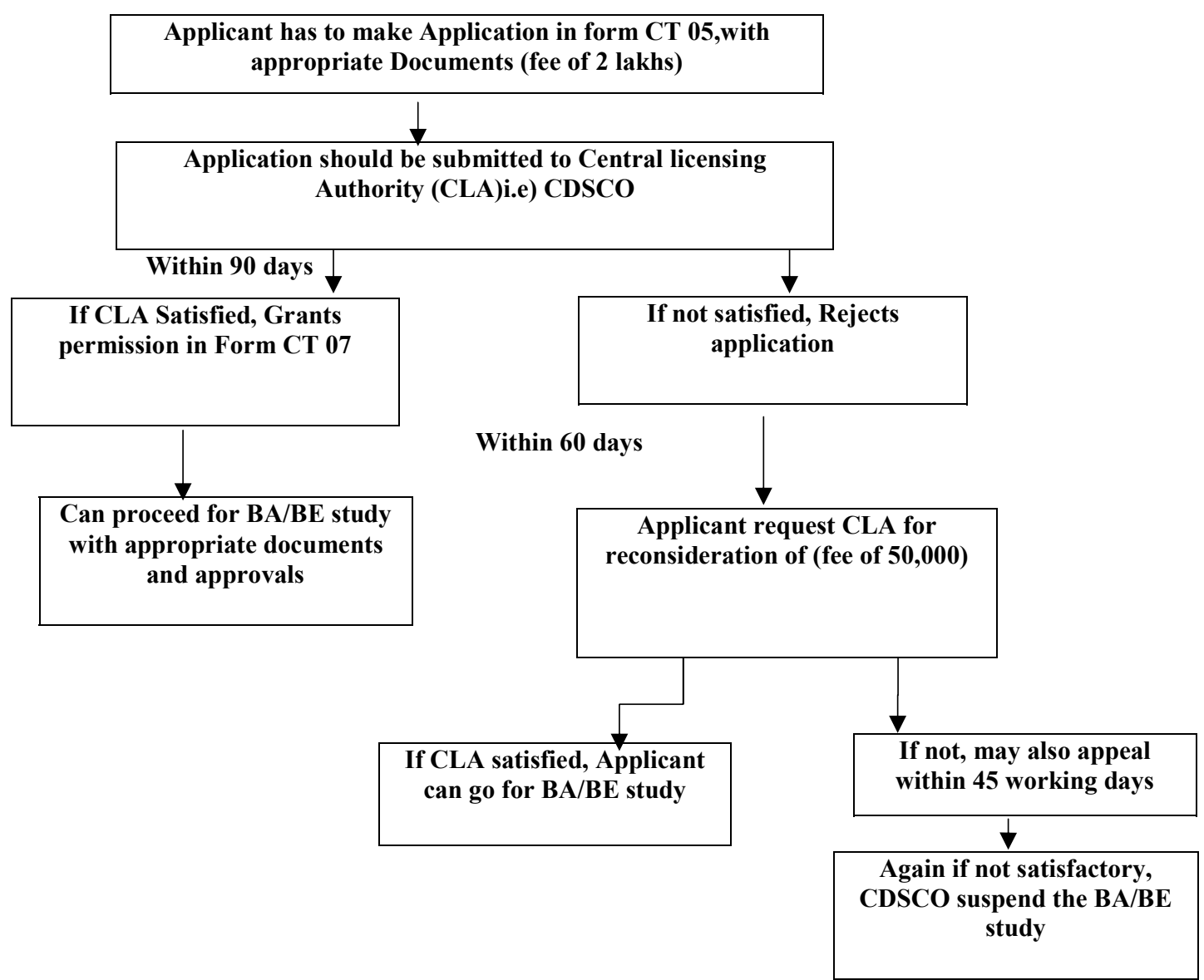

\section{CONCLUSION}

The NDCT Rule 2019 undoubtedly paved an opportunistic way for Indian Pharmaceutical Global Market. As wellknown fact, India is largest supplier of Generic product of about $20 \%$ exports. The new rule provided fast rack approachability for registration of $\mathrm{BA} / \mathrm{BE}$ Study and $\mathrm{BA} / \mathrm{BE}$ study center, Stringent Regulation of Bio equivalence will help to ensure compliance of guidelines while performing studies. Likewise, The Expeditious approval of clinical trial in India will boost and encourage leading pharma company to perform clinical trials in India and also Regulation of Clinical Trial matches with
Global standard. As result, it will encourage clinical trials in India and also increases global values of India on Generic Drug Market. NDCT Rule will support the Recent Discussion of DCGI India to follow ICH Guidelines in future.

\section{REFERENCE}

[1] Thorat S, Banarjee S, Gaikwad D, Jadhav S, Thorat R, Clinical trial: A review International Journal of Pharmaceutical Sciences Review and Research, (2010).

[2] Gogtay NJ, Ravi R, Thatte UM, Regulatory requirements for clinical trials in India What 
academicians need to know, Indian J Anaesth, 61(3), 2017 Mar, 192-199.

[3] Huang W, Percie du Sert N, Vollert J, Rice ASC, General Principles of Preclinical Study Design, Bespalov A, Michel M, Steckler T, Good Research Practice in Non-Clinical Pharmacology and Biomedicine, Handbook of Experimental Pharmacology, vol 257, Springer, Cham. https://doi.org/10.1007/164_20 19277.

[4] New drug and clinical trial rules 2019, Available on CDSCO (https://cdsco.gov.in/opencms/o pencms/en/Clinical-

$\underline{\text { Trial/clinical-trials/). }}$.

[5] Zaman, Muhammad \& Adnan, Sherjeel \& Farooq, Muhammad \& Aun, Ali \& Yousaf, Muhammad \& Naseer, Ayesha \& Shareef, Maryam, A Comprehensive Review on Bioequivalence Studies in Human Subjects, British Journal of Pharmaceutical Research, 11. 1-8, (2016), 10.9734/ BJPR/ 23976.

[6] Bose A, Ghosh B, Manda PT, New Drugs and Clinical Trials Rules-2018” (GSR-104 E) by
CDSCO: It's Impact on $\mathrm{BA} / \mathrm{BE}$ Studies in India. Pharm Regul. Aff Open Access. 2018; 7(2): 1000208. doi: 10.4172/ 21677689.1000208.

[7] Godbillon J, Cardot, JM, Lecaillon JB, Bioequivalence assessment: a pharmaceutical industry perspective. European Journal of Drug Metabolism and Pharmacokinetics 21, 153-158. (1996), https://doi.org/10.1007/ BF03190264. 